\title{
Superficial Soft Tissue Fibrosis
}

National Cancer Institute

\section{Source}

National Cancer Institute. Superficial Soft Tissue Fibrosis. NCI Thesaurus. Code C78633.

Fibrotic degeneration of the superficial soft tissues. 